\title{
Heterogeneous Landscapes: From Theory to Impact
}

\author{
Marietta Horster
}

Authors and editors of such a landscape-related volume "create" the outlines of their respective ancient landscapes and define the specific Roman-ness of this landscape's existence. Therefore, the subject is broad if not vast. The individual researcher fixates the borders of a landscape: these may be natural such as mountains or rivers, social such as dwellings, cities, cultivation or mining areas, political such as physical frontiers between states or administrative boundaries between civic territories or provinces as well as imaginary, such as those between two book covers. Landscapes are established by the humans acting and reacting within a given space and in different periods of time. They may be formed by visual, verbal or digital media, characterised by the parameters applied and defined by the respective research project. The number of such parameters seems to be endless, either encompassing a kind of generic level of landscapes as emotional, social, sacred, poetic, epic, economic, maritime etc., ${ }^{1}$ or capturing a more specific landscape like Gainsborough's or Ovid's, Roman, German or Egyptian. ${ }^{2}$ Apart from this delineated scheme of a variety of envisioned landscapes, one might draw a physical map of landscapes as well, however, equally determined by theoretical preconditions and decisions.

The evidence for environmental, social and economic conditions of a given region is growing with shifts in interest of archaeological and historical studies. Refined methodologies of regional surveys as well as the adoption of geological, biological and other technologies and multi-scalar approaches in pre-modern historical contexts give insights into "lived" landscapes. ${ }^{3}$ Surveys provide data for the analysis of small scatters and soil samples. These permit the investigation of

1 E.g. the modelling of a maritime landscape establishes a network of shipwrecks, harbors, seaborne connectivity, hinterland activities and more such categories, see J. Leidwanger, Roman Seas: A Maritime Archaeology of Eastern Mediterranean Economies, (Oxford 2020), 69-109.

2 E.g. S. Sloman, Gainsborough's Landscapes. Themes and Variations (London 2011); C.E. Barrett, Domesticating Empire: Egyptian Landscapes in Pompeian Gardens (Oxford 2019).

3 For the anthropological dimension of the landscape theory see T. Ingold, 'The temporality of the landscape', WorldA 25 (1993), 152-172, here 152. A summary of some of the many critical engagements with Ingold's "temporality" and "taskscape"-ideas is to be found in D. Hicks, 'The temporality of the landscape revisited', Norwegian Archaeological Review 49 (2016), 5-22. Different categories within an anthropological plus social theory approach to spatial aspects of landscape (e.g. existential, somatic-unconscious or cognitive-theoretical categories) are 
settlement patterns, demographic changes, dietary habits, infrastructure developments, connectivity or trade flows. Some such survey-based studies analysing traces of human activities and changes in climate and environment have modified our understanding of republican Italy or imperial Greece. 4

Recent decades have shown an increasing sensitivity to the time dimension and ontology, as material and ideal entities are not associated with a specific point in time. Rather, objects of everyday life or built structures, for example, as well as literary and artistic products reflect the memories, tastes and preferences that have formed and accumulated over a shorter or longer period of time and were used over generations. Activities, movements, perceptions, emotions etc. are inscribed in the landscape and have merged in objects, which were produced out of a specific social practice at any given time. This "hybridity" of everything and everyone has been given a theoretical background with the "third space theory" that was applied in the field of archaeology, whereas the acceptance of the precondition of embeddedness in traditions and hybridity of textual evidence has long since been established in the research of classicists without making use of the specific "third space" term. ${ }^{5}$ The classified

discussed by C. Tilley, A Phenomenology of Landscape. Places, Paths, and Monuments (Oxford 1994), passim and esp. 16-17.

4 A. Casarotto, Spatial Patterns in Landscape Archaeology. A GIS Procedure to Study Settlement Organization in Early Roman Colonial Territories (Leiden 2018) compares different methods, their effects and results. For obvious changes in settlement patterns not all following the same model and having the same impact in the Italian regions, see e.g. E. Antonacci Sanpaolo, 'Landscape changes: romanization and new settlement patterns at Tiati', in S. Keay and N. Terrenato (eds.), Italy and the West. Comparative Issues in Romanization (Oxford 2001), $27-38$. With an overview of the ongoing discussion concerning developments of more or less dramatic changes of landscapes in post-Hannibal Italy triggered by demographic change, Roman land distribution and land use: L. de Ligt and S. Northwood, 'Introduction', in L. de Ligt and S. Northwood (eds.), People, Land, and Politics. Demographic Developments and the Transformation of Roman Italy 300 BC-AD 14 (Leiden and Boston 2008), 1-14. For Greece, see S. Alcock, Graecia Capta. The Landscapes of Roman Greece, (Cambridge 1993).

5 R. Bernbeck, "Squatting" in the Iron Age: an example of third space in archaeology', eTopoi. Journal for Ancient Studies 8 (2019), 1-20 providing a rich bibliography and an introduction into the "third space" theory and its rooting in post-colonial, sociological and philosophical studies. Better manageable is the adaptation of A. Haug in her paper 'Visual concepts in human surroundings: the case of the early Greek polis (10th-7th century BC)', in A. Haug, L. Käppel and J. Müller (eds.), Past Landscapes. The Dynamics of Interaction between Society, Landscape, and Culture (Leiden 2018), 145-168. Haug 'translates' the theoretical concept of "lived space, conceived space, perceived space" with the terms "built environment, visual concepts, representations". She elucidates (p. 164-165) that there is no antithetical relationship of "Lebenswelt and Bilderwelt"; images are not a simple reflection of lived space, and the relation between the "spaces" underlies changes. For the appropriation of the third-space concept in historiography, see J.M. Vonder Bruegge, Mapping Galilee in Josephus, Luke, and 
objects and samples within the context of landscape research are, however, defined by timeframes as e.g. the date of production, first usage, last access or the stratum in which they were found. The fruitful discussion on landscape theories has given more prominence to the objects (material, verbal) as agents, to the difficulties of defining specific layers of impact and agency, and to the researchers, authors and museum curators as being actors in creating the landscapes (not to mention e.g. the readers and visitors of an exhibition or archaeological park). Notwithstanding the creativity and openness of mental maps and landscapes created by literature and art, not all landscapes are static or dynamic. A landscape is not merely a passive representation or symbol. It is itself actively exerting influence on human activities, decisions and perceptions, and can ultimately be instrumentalised in a power relation. ${ }^{6}$

Landscape is a land shaped. ${ }^{7}$ It is part of the past, a product of the past and a product of previous and present archaeological, historical, philological or artcreating praxis. This, and any other definition of "landscape" as an analytical term, will inevitably be vague and imprecise as too many different disciplinary approaches have contributed well-argued phrases (see below). Two rather general concepts are the following: the term landscape denotes "the arrangement and interaction of peoples and places in space and time" and are thus "spatial correlates of human behaviours". "Landscape can be seen as a specific segment

John: Critical Geography and the Construction of an Ancient Space (Leiden/Boston 2016), $5^{\mathrm{o}-86 .}$

6 W.J.T. Mitchell, 'Introduction', in W.T.J. Mitchell (ed.), Landscape and Power (Chicago and London 1994, repr. 2002), 1-4. Tilley 1994 op. cit. (n. 3), 35-70 on the social construction of landscapes in small-scale societies representing and influencing power relations.

7 Etymology cited by P. Gruppuso and A. Whitehouse, 'Exploring taskscapes: An introduction', Social Anthropology - Anthropologie Sociale 28 (2020), 588-597, here 591. They discuss the influential, different landscape theories of T. Ingold 2013, op. cit. (n. 3) and K. Olwig, cf. K.R. Olwig, 'Performing on the landscape versus doing landscape: Perambulatory practice, sight and the senses of belonging' in T. Ingold and J.L. Vergunst (eds.), Ways of Walking: Ethnography and Practice on the Foot (Aldershot 2008), 81-91. M. Teichmann, Mensch und Landschaft im südwestlichen Latium in der römischen Antike (Wien 2017), 17-28 presents a critical overview of landscape archaeology approaches categorised into contemporary "Schulen".

8 Alcock 1993, op. cit. (n. 4), 6 and ibid. "Usages of the term are also bound together by an emphasis upon landscape as a social product, the consequence of a collective human transformation of the physical environment. Human activity, human involvement forms the key element: landscape is "never simply a natural space" with the last words referring to J.B. Jackson, Discovering the Vernacular Landscape (New Haven 1984), 7-8. 
of space, constructed through permanent processes of meaning-making and boundary-production, and is therefore always connected with multiple perceptions." ${ }^{9}$ Davidovic therefore recommends that a researcher should qualify the usage of the word by an attribute, or address specific ecological and physical elements, or use terms other than environment. The major difference in the usage (and definition) of the term "landscape" arises when it comes to addressing either the cultural product or the physical entity. However, temporality, interrelatedness and processes of development and change are part of both concepts - the physis as well as the cultural construct. Whatever definition one applies, landscapes are simply shaped by human activity - the "physical" by more or less intensive interventions in an environment, the "imagined" by an artist or an author, and all of them combined by the observer's perspective, which ultimately decides which landscape "exists".

The interactions, perceptions and traditions of social groups have a different impact on landscapes. ${ }^{10}$ The human imprints in an environment such as the division and organisation of land into areas of sacred use or agricultural production are determined by natural conditions of geomorphology and climate, and the human conditions of social structures and symbolic systems. ${ }^{11}$ The landscape created in this manner is not static as long as social activities take place. In turn, such a landscape has an impact on the determinants and can thus also influence, for example, the climate, soil quality, social structure, demography and political organisation. Landscape is therefore not just "qualitative and heterogeneous", but also "a contoured and textured surface replete with diverse objects" in which every new "addition" is a "reworking". ${ }^{2}$

9 A. Davidovic, 'On melting grounds. Theories of the landscape', in Haug et al. 2018, op. cit. (n. 5), 53-72, here 53 .

10 A very wide appropriation of the term was chosen by the initiators of 'Graduate School for Human Development in Landscapes' (GSHDL) at the German University of Kiel, see J. Müller, 'Landscape and the GSHDL, 2007-2017: Ten years of research', in Haug et al. 2018, op. cit. (n. 5), 17-36. They defined four "spheres of landscapes" 1) ritual landscape (cult activities, holy places and monuments, burial practices etc.); 2) social landscape (social strategy and behaviour, social stratification, political institutions etc.); 3) economical landscape (food production, clothing, house building, urbanization, craftsmanship etc.); 4) ecological landscape (climate; geomorphology, soils, vegetation, humans etc.). Another publication of this GSHDL was published in 2012 by 11 doctoral students: F. Förster et al., 'What is a landscape? Towards a common concept within an interdisciplinary research environment', eTopoi 3 (2012), 169-179. For a less integrating, sharper distinction of the term, see Th. Meier, 'Umweltarchäologie - Landschaftsarchäologie', Historia Archaeologica 70 (2009), 697-734, underlining that landscape-studies are related to a historical approach, whereas environmental studies are more related to the sciences.

11 Müller 2018, op. cit. (n. 10), 25.

12 Ingold 1993, op. cit. (n. 3), 154. 
Underlining the temporality of the landscape, Ingold's ideas are paring the idea of accumulation, dynamics and hybridity of objects in the above mentioned third space theory. Ingold and others insist that a separation between the notions of culture and nature does not make sense at the level of landscape definition. Most obviously, the tradition of literary and artful products would evolve. Following this convincing assumption, the landscape of exempligratia Campania changed after the publication of after Statius's poems not only in the world of the literati, but also for the educated public in historical times as well as our own.13

The notion of landscape therefore has four coordinates 1) space, 2) time, 3) one or more 'historical' actor(s) or social interactions, 4) the (modern) observer, defining the landscape as such. In the landscape-context, (modern) observation thus takes the role of Paasi's "external recognition" in shaping space as a region. ${ }^{14}$ Insofar, this volume inscribes itself in the long list of landscape studies as one study of "the temporality of the landscape revisited". 15 This includes material as well as imagined spaces, though both reflect an "interim outcome of a long-standing and complex interplay" of agents, structures and processes. ${ }^{16}$ We should be aware that, at least in the material world, nature and climate are agents as well, taking part in the creation of a landscape not just once but over time. Landscapes are more than the outcome of human action and experience; they are the outcome of a process in which humans "integrate their physical environment in their understanding of the world". ${ }^{17}$ The following selection of characteristics and aspects is primarily intended to offer the

13 With further references see J.L. Smolenaars, 'Ideology and poetics along the Via Domitiana: Statius Silv. 4.3', in R.R. Nauta (ed.), Flavian Poetry (Leiden 2006), 223-244; A. Agoustakis, 'Campania in the Flavian poets' Imagination', in A. Agoustakis and R.J. Littlewood (eds.), Campania in the Flavian Poetic Imagination (Oxford 2019), 3-12.

14 A. Paasi, "The resurgence of the "region" and "regional identity": Theoretical perspectives and empirical observations on regional dynamics in Europe', Review of International Studies 35 (2009), 121-146, here 133-137, the other ingredients for defining a region are territory, borders, institutions and symbols. F. Carlà-Uhink, The 'Birth' of Italy: The Institutionalization of Italy as a Region, 3rd-1st Century BCE (Berlin 2017), 15-18 engages with Paasi's concept and applies aspects of it profitably to his study of Roman Italy.

15 D. Hicks, 'The temporality of the landscape revisited', Norwegian Archaeological Review 49 (2016), 5-22.

16 J. Kolen and J. Renes, 'Landscape biographies: key issues', in J. Kolen, J. Renes and R. Hermans, Landscape Biographies. Geographical, Historical and Archaeological Perspectives on the Production and Transmission of Landscapes (Amsterdam 2015), 21-48, here 28.

17 J. McInerny and I. Sluiter, 'General introduction', in J. McInerney and I. Sluiter, (eds.), Valuing Landscape in Classical Antiquity. Natural Environment and Cultural Imagination (Leiden and Boston 2016), 1-21, here 2. 
larger framework, both for the landscapes and for the variants and modalities of Impact of the Roman Empire discussed in the present volume.

\section{Social and Economic Aspects}

Roman aggressive, imperialistic activities concerned forced population movements such as those of the Ubii, Cananefatii or Nemetii in the early first century CE), ${ }^{18}$ colonisation and land distribution..$^{19}$ These measures had an immediate impact on social relations and the economic systems. The results of land division (centuriae), the distribution of quality land to settlers and the notification of undistributed land were put on public display. The overall volume and size of plots of the allocated land depended on the number of settlers, but there existed standards of size in a given time..$^{20}$ Neighbouring land not divided was called subseciva. ${ }^{21}$ The fair distribution was thus demonstrated by centuriation records as well as the correct work of the land surveyors. Later disputes should thus be avoidable as far as possible. The maps and the inscriptions connected with it created a landscape related to the Roman law, which could only be changed by legal intervention. ${ }^{22}$ Some land division had been massive, under Sulla up to 80,0oo veterans were settled in Italy, Pompey's and later Octavian's veterans were rewarded in Italy and in the provinces: ${ }^{23}$ making

18 H. Galsterer, 'Gemeinde und Städte in Gallien und am Rhein', in G. Precht and N. Zieling (eds.), Genese, Struktur und Entwicklung römischer Städte im 1. Jahrhundert n.Chr. in Nieder- und Obergermanien (Mainz 2001), 1-9, bes. 4.

19 For further literature on centuriation and the distribution of land in the context of colonisation see Günther Schörner in this volume, and B. Campbell, Corpus Agrimensorum Romanorum. The Writings of the Roman Land Surveyors. Introduction, Text, Translation and Commentary (London 2000), XXVII-XLIV with an overview of the antique authors and the contents of the extant collection.

20 Campbell 200o, op. cit. (n. 19), XLIV-LXI with a summary of the Roman land division and allocation history in the context of colonisation. Often land plots had the length of 20 actus (ca. 706m) per colonist (cf. LVII).

21 J. Hettinger, 'Neues zum Kataster von Lacimurga. Die Darstellung der subseciva entlang des Ana', Chiron 47 (2017), 189-212 presents sources and debates concerning subseciva and interprets the visual presentation of the subseciva in the Lacimurga-fragment as floodplains of the river Ana, therefore unsuitable for agricultural use.

22 Campbell 200o, op. cit. (n. 19), XLV-LIII for the development of surveying. On public documentation and its legal context, see e.g. for Urbicus, Campbell 20oo, ibid., XXXII (legal training), Hyginus 1, ibid., XXXV-XXXVI (respect law and seek legal advice); Hyginus 2, ibid., XXXVII (record settlement and document relevant features on bronze map).

23 A. Thein, 'Sulla's veteran settlement policy', in F. Daubner (ed.), Militärsiedlungen und Territorialherrschaft in der Antike (Berlin 2010), 79-99. 
use of the conquered land and the property of the defeated people was less symbolic than real. However, it seems that at least in parts of central and south Italy, the Romans had no plan for an overall reconstruction of these regions after their punitive and ravaging activities. ${ }^{24}$

The long term effects of this migration and changes in ownership structure on the economic, cultural, and political landscape was a Romanisation in the proper sense of the word. It might have turned though into intercultural exchange by marriages, trade, and interconnectedness and identification of the new settlers with the region. Many less obvious Roman and probably even more pro-, inter- and re-active undertakings by other agents influenced and accelerated, changed or slowed down processes of changes of the social landscape. Such massive social-economic changes are sometimes still visible in the ground and in aerial photography like e.g. in the centuriated field systems visible in the territories of Pola, Iader and Salona in Roman Dalmatia. ${ }^{25}$

Research based on surveys offer clues to study exploitation intensity and kind. They provide main indicators for changes in social behaviour and economic preferences and choices. Demography and settlement studies allow insights into the life of the populace without reducing them to a conquered population. With a focus on economy, some surveys have revealed that Rome's domination and the possibilities of empire-wide sales markets were by no means a great stimulus for all regions of the Imperium Romanum. Furthermore, a large part of the economy remained entrenched in a local context. However, the precise dating of the ceramic data and the respective inference of a corresponding density of the rural population in a specific century and historical context proved challenging. ${ }^{26}$ Despite these methodological difficulties in biases of attributing data to chronology, there is enough context-related and well-dated material to discern that some regions were among the losers after the integration into the Roman empire. This concerns e.g. parts of Italy in the republican time and the late antique period and some parts of Greece in the

24 E. Bispham, From Ausculum to Actium. The Municipalization of Italy from the Social War to Augustus (Oxford 2007), 407-412.

25 For aerial photography and other means and methods of investigation and analysis, see H.A. Orengo, J.M. Palet Martínez, 'Methodological insights into the study of centuriated field systems: a landscape archaeology perspective', Agri Centuriati 6 (2009), 171-185.

26 P. Attema, T. de Haas and G. Tol, 'Concluding remarks' in P. Attema, T. de Haas and G. Tol (eds.), Between Satricium and Antium. Settlement Dynamics in a Coastal Landscape in Latium Vetus (Leuven 2011), 81-82. Similar, J.A. Barceló and M. Pallarés, 'Beyond GIS: the archaeology of social spaces', Archeologia e Calcolatori 9 (1998), 47-8o here 63-69 underline the importance of hypothesizing relationships between activities and findings that produced a specific cluster of objects. 
Imperial period ${ }^{27}$ For example, the expansion of a port-city might have negative consequences for nearby smaller centres, as seen in the region around Italian Brundisium. ${ }^{28}$ Global economy seemed to have threatened some of the Italian produces, whereby Trajan introduced protective measures for Italian viniculture. In the provinces, other measures were taken to maintain a solid economic base and with it secure the corresponding tax revenues on land for the Romans, and for customs duties on agricultural products that entered inter-regional trade. ${ }^{29}$ There was no reason to intervene in the case of land under continuous cultivation, whereas land that was often flooded, washed away or sanded up needed special treatment. In imperial Roman Egypt, there existed short-term lease-contracts for such "substandard land" categories with very low rent in kind or money. ${ }^{30}$ Here as well as in other provinces, the positive, reinforcing measures consisted of either long-term fiscal relief or tax exemption for a given period of time to those willing to cultivate abandoned land. ${ }^{31}$ The so called early-second century lex Manciana, a contract of which copies are known from Africa Proconsularis (CIL VIII 25902 with AE 1998, 1579; 2001, 2083) offered, as it seems, attractive sharecropping regulations to farmers on imperial estates in the Bagradas Valley, perhaps to further the intensification

27 Attema, de Haas and Tol 2011, op. cit. (n. 26), 81 summarise for post-archaic, pre-Roman Latium a "sharp decrease in the number of rural sites", an average performance between 350-30 BCE, and an increase by the Augustan period. See ibid, 71 a distribution map of imperial sites; ibid., 73 reduction in 250-40o CE; ibid., 75 sharp break since 400 CE; Alcock 1993, op. cit. (n. 4), 91 n. 9o, 243 on agri deserti and emphyteutic legislation.

28 R. Witcher, 'The global Roman countryside: Connectivity and community', in T. de Haas and G. Tol (eds.), The Economic Integration of Roman Italy. Rural Communities in a Globalizing World (Leiden 2017), 28-50.

29 As concerns agricultural production and consumers' preferences and needs, Bang underlines the impact of the extreme geographic variation in the Roman empire and e.g. the erratic rainfall in many regions. Market activities or the potential of such undertakings reflect the ecological conditions as well as social and cultural demands. B.F. Bang, 'Imperial bazaar: towards a comparative understanding of markets in the Roman empire', in P.F. Bang, M. Ikeguchi and H.G. Ziche (eds.), Ancient Economies, Modern Methodologies, Archaeology, Comparative History, Models and Institutions (Bari 20o6), 51-88, esp. $5^{6}$ discussing arguments of P. Horden and N. Purcell, Corrupting Sea (Oxford 2000).

30 J. Rowlandson, Landowners and Tenants in Roman Egypt. The Social Relations of Agriculture in the Oxyrhynchite Nome (Oxford 1996), 8o-88 for the filling of vacant tenancies for public land of low quality and little return.

31 See above for imperial Greece (n. 27), for Roman Egypt (n. 30) and for subseciva in the provinces (n. 21). For late antique legislation concerning such issues, see D. Bar, 'Roman legislation as reflected in the settlement history of late antique Palestine', Scripta Classica Israelica 24 (2005), 195-206 and Francesco Bono in this volume. 
of agriculture.$^{32}$ Investments in water management and in product processing such as crushing olives, milling grain, cutting wood, extracting stones increased the return of the individual tenant or proprietor as well as the overall economic performance of a region and had an impact on the rural landscape. Efficiency and intensification of labour, e.g. the increased use of draught animals may, however, not always been in the interest of the tenants, who had to invest in donkeys and feed them..$^{33}$ In addition, some of the Roman legal arrangements and provisions, such as those for water rights, not only had economic consequences for farmers in rural communities but changed social relationships of neighbours, including those in need of water to increase their private comfort and to decorate their villas with artificial water features. ${ }^{34}$ Differences in Rome's reaction to regional requests thus depended inter alia on the potential of the environment, the plant regime and water management, and the specific patterns of exploitation as part of agricultural strategies. ${ }^{35}$

Social groups and interactions determined settlement structures, which had to follow the natural conditions of the land. Geophysical surveys are effective means of "making visible the spatial layout and character of buried remnants of identified settlements and identifying hidden sub-surface traces of human activities in the landscape." ${ }^{36}$ However, it is difficult to understand and define the quality of rural sites: the remains may have been those of permanent farmsteads or seasonally occupied field houses. Other interpretation patterns have more validity and are connected to the quality and quantity of findings, like the differentiation between nucleated or dispersed settlements and between

32 L. de Ligt, 'Studies in legal and agrarian history I: the inscription from Henchir Mettich and the Lex Manciana', Ancient Society 29 (1998-1999), 219-229; M. de Vos, 'The rural landscape of Thugga: farms, presses, mills, and transport', in A.K. Bowman (ed.), The Roman agricultural economy. Organization, investment, and production (Oxford 2013), 143-218, esp. 146.

33 The tenants-coloni of imperial land in North Africa as in Egypt and few other regions had the option of putting pressure on the imperial procurator by threats of leaving the leased imperial land for privately owned land, see D. Kehoe, The Economics of Agriculture on roman Imperial Estates in North Africa (Göttingen 1988), 79-90.

34 C.J. Bannon, Gardens and Neighbors. Private Water Rights in Roman Italy (Ann Arbor 2009); C. Möller, Die Servituten. Entwicklungsgeschichte, Funktion und Struktur der grundstückvermittelten Privatrechtsverhältnisse im römischen Recht. Mit einem Ausblick auf die Rezeptionsgeschichte und das BGB (Göttingen 2010), 78-9o and 317-364.

35 See e.g. De Vos 2013, op. cit. (n. 32); K. Blouin, Triangular Landscapes. Environment, Society, and the State in the Nile Delta under Roman Rule (Oxford 2014); J.C. Wright, J.L. Davies and J.F. Cherry, 'Foreword', in E.-F. Athanassopoulos, Landscape Archaeology and the Medieval Countryside. Nemea Valley Archaeological Project 2 (Princeton 2016), VII-X, esp. VIII; Athanassopoulos, ibid., 22-24.

$36 \quad$ Müller 2018 op. cit. (n. 10), 25 . 
dominance of transhumance or animals in small herds, which allowed easy manuring the fields. These alternatives reflect different agricultural strategies and patterns of land tenure. ${ }^{37}$ Archaezoological and botanical data and analysis give insights into land use, choices of crops or market production such as fruits and olives. Findings represented by histograms and period maps open up many research possibilities and methodological approaches to study developments within an area and variations between areas. ${ }^{38}$ The quality and diversity of data have increased throughout the last decades, not only in terms of the results of surveys and excavations, but also due to new field methodologies, analytical techniques and focal points briefly listed here following de Haas' and Tol's introduction to her Italy-related volume: the intensive off-site field methods, the application of geophysical prospection, refined geo-archaeological and paleo-environmental studies, a new focus on rural sites, the use of ecological sampling and the advancement in digital recording (like photogrammetry) and technologies (like handheld XRF). ${ }^{39}$

The integration of highly urbanised regions, i.e. parts of Italy, Greece and coastal Asia Minor, the encouraged or enforced urbanisation of some Western and Eastern regions and the administrative structuring in provincial units was of major importance for an effective Roman control of its empire. The wealth and strength of the individual cities with their respective provincial performance as tax-payer and as a multiplier of Roman culture and the imperial cult most often depended on the size of the territories, the quality of the soil and its ecological potential, the size of landed property and the number of its citizens. Densely populated and highly urbanised regions or provinces produced different sacred, demographical, economic, power etc. landscapes compared to remote, soldier-dominated and probably rather poor regions like that around Mainz. ${ }^{40}$

Evidently, settlement structures, land ownership, the distribution of wealth and income and ostentation of status and resources influenced the social landscape. It is also obvious that there existed more manifestations of social life and

37 The two sentences above follow closely the text of Athanassopoulos 2016, op. cit. (n. 35), 22.

38 See e.g. the graphs in Attema, de Haas and Tol 2011, op. cit. (n. 26), 53-8o.

39 T. de Haas and G. Tol, 'Introduction', in Haas and Tol 2017 op. cit. (n. 28), 1-12, esp. 2.

40 Moguntiacum near the border of Roman Germania Superior, though, had an enormous theatre not only for the soldiers stationed here. It had harbour facilities and lay at the crossing of two rivers, attractive for traders and important for Roman defense strategies. With rather similar characteristics as concerns the dominance of soldiers in the region, their needs and preferences, military veteran settlement and demographical changes, see M. Fulford, 'Roman Britain: immigration and material culture', in H. Eckardt (ed.), Roman Diasporas. Archaeological Approaches to Mobility and Diversity in the Roman Empire (Portsmouth 2010), 67-78. 
social structures such as gender, identity groups, dwellings for slaves or tenants, training grounds for boys or cemeteries, to name but a few. The "landscapes of death" often began immediately outside the gates of a city. ${ }^{41}$ The city wall was, however, no dividing line between life (city) and death (cemeteries outside). Burial preparation rituals commenced wherever the death had occurred, be it in- or outside the city walls. ${ }^{42}$ Cemeteries and single funerary monuments were meeting places of the living with the dead rather than inanimate spaces: libation conduits, offering tables, mensa tombs and accommodated banquets attest the ritualised and regular communication in Roman-styled and locally-adapted graveyards. The decision between cremation or inhumation had consequences for the rituals and arrangements of funerary places. ${ }^{43}$ Diverse locations and topographical conditions, catacombs and hills strewn along overland roads or hidden in the hinterland indicate the great variance in the framework conditions that existed for the landscapes of death - not to mention specific contexts such as that of remembering fallen soldiers without a graveyard but with a monument of victory on the battlefield (tropaium). In addition, there were regional traditions in the design of larger tombs and the arrangement of smaller burial grounds. ${ }^{44}$

41 For the terminology of landscapes and the subject of relation of tomb and landscape, see D.L. Stone and L. Stirling, Mortuary Landscapes of North Africa (Toronto 2007), 3-31 and C. Botturi, "Landscapes of life" and "landscapes of death": the contribution of funerary evidence to the understanding of the perception and organisation of Roman rural landscapes in northern Italy', in M.J. Mandich et al. (eds.), TRAC 2015. Proceedings of the 25th Annual Theoretical Roman Archaeology Conference (Oxford 2016), 43-56.

42 For an introduction into the Roman in contrast to the Greek ritual of death, see I. Morris, Death-Ritual and Social Structure in Classical Antiquity, Cambridge 1992, 31-69 with further literature.

43 Ahrens, S. (2015), “Whether by decay or fire consumed ...": cremation in Hellenistic and Roman Asia Minor', in J.R. Brandt et al. (eds.), Death and Changing Rituals. Function and Meaning in Ancient Funerary Practices (Oxford 2015), 185-222, here 200 and 208 on cremation in Greece and western Asia Minor as an acculturation process in the Roman imperial period perhaps in connection with West-East migration at least in the regions Galatia and Paphlagonia. With a different conclusion, P. Johnson, 'How did the landscape of Pompeiopolis become Roman?', in K. Winther-Jacobsen and L. Summerer (eds.), Landscape dynamics and settlement patterns in northern Anatolia during the Roman and Byzantine Period (Stuttgart 2015), 61-82: typical rock-cut tombs and new local style burial tumuli are part of a Paphlagonian-Roman dialogue, but more important for the impression of a Roman landscape was its prosperity and the density of the settlement. For the (methodological) difficulties to identify immigration by burial style and cemeteries, see J. Pearce, 'Burial, identity and migration in the Roman world', in H. Eckardt 2010, op. cit. (n. 40), 79-98.

44 There is an immense amount of publications on the regional aspect of this subject, see e.g. for the Northwestern Provinces, N. Laubry, 'Aspects de la romanisation en Gaule et 
Depending on the focus and research questions, "social landscapes" come to life in different ways. They can be defined by investigating ceramics and gravestones, house structures and ritual or literary spaces. Landscape composed of social structures and symbolic systems represented by objects, interactions and rituals create a "dynamic, functional, and symbolic network". 45 It is assumed that there was a connection between objects, texts, people and environment, and that people (living or dead, real or imagined) interacted and communicated within these spaces. Apart from military strength it was, above all, the interconnectedness of administrative structures, geographical spaces, trade routes and communication channels that held the Roman empire together. Accordingly, infrastructure through road construction, politically connoted landmarks such as milestones, but also impressive aqueducts and long-distance water pipes played an important role in the border-transgressing creation of Roman landscapes in Italy and the provinces.

\section{Connectivity and Infrastructure Contexts}

The organisation of communication, transportation and traveling by overland, riverine and maritime networks was a common feature of pre-modern societies. ${ }^{46}$ Differences in the demand for speed, in the topographical features, the needs for supply of larger communities, the organisational level of the administration, cultural choices of transport preferences and technical provisions and other conditions had a major impact on the road systems. Roman

en Germanie : les monuments et les inscriptions funéraires sous le Haut-Empire', Pallas 8o (2009), 281-305. M. Scholz, Grabbauten des 1.-3. Jahrhunderts in den nördlichen Grenzprovinzen des Römischen Reiches, Mainz 2012; S. Esmonde Cleary, 'Putting the dead in their place: burial location in Roman Britain', in J. Pearce, M. Millett and M. Struck (eds.), Burial, Society and Context in the Roman World (Oxford 2015), 127-142; M. Monteil and W. van Andringa, 'Hoc monimentum maesoleumque: les monuments funéraires dans le paysage des cités des Gaules et des Germanies romaines', Gallia 76 (2019), 1-8.

45 Botturi 2016, op. cit. (n. 41), 51.

46 S.E. Alcock, J. Bodel and R.J.A. Talbert, 'Introduction', in S.E. Alcock, J. Bodel and R.J.A. Talbert (eds.), Highways, Byways, and Road Systems in the Pre-Modern World, New York 2012,1-11, present an outline of the studies in the volume from the second millennium BCE to the nineteenth century $\mathrm{CE}$ and concerns societies on four continents. Even in strong empires like China and Japan, in some periods rich individuals as well as local communities dominated infrastructure work and maintenance (id., 3-4). During the centuries of Roman dominance, communities had to invest and maintain parts of infrastructure, either judicially preassigned or of practical necessity, see e.g. T. Kissel, 'Road-Building as a Munus Publicum', in P. Erdkamp (ed.), The Roman Army and the Economy (Amsterdam 2002), 127-16o, here 133-157. 
decisions and investments in the development of road networks and of waterways, e.g. by anti-silting measures, caused profound changes to the economy of a region. Not all built infrastructure under a certain regime had to be part of an overall (spatial) planning or the outcome of a requirement analysis. In terms of historical societies and their governments, it is not always possible to evaluate the quantity and quality of the roads, the functionality of the road systems and network-designs compared to previous systems in the same region, to other regions and/or societies. Despite an intensive and decades-long research of Roman roads and networks, there are still methodological problems of classification and functionalities. ${ }^{47}$ These concern such rather banal assessments such as road classifications, in contemporary or later sources described as broad, convenient, highway-type and costly (or in the Roman language as consularis or militaris). The presumption that the existence of roads ensures safe transport and comfortable travelling merges with the visible structures and changes. One such example is the Venetian plain south of Padua, which was covered by a Roman road network with effects on the environment as well as the visual and emotional but also the economic and political landscape. ${ }^{48}$ In some infrastructure-strong regimes like the Roman, extensive remodelling of the landscape may also have served "to impress upon the population the proud grip imposed by a dominant power" as one interpretation of Inca investment into road building connected to social engineering of reshaped communities and residential areas in the $15^{-16 \text { th }}$ centuries has suggested. ${ }^{49}$ The high connectivity of the Roman empire, as a consequence, has boundary transgression of provincial administrative and political structures, not just by its road network, but also by aqueducts passing over and through civic territories. ${ }^{50}$ An augmented transhumant pastoralism by large-scale flocks was part of the augmented Roman demand of animal-products (e.g. wool and meat) and required an extension of pastoral movements. ${ }^{51}$

47 For the impact of Roman investment into infrastructure on economy and regional hierarchies, see T. de Haas, 'The geography of Roman Italy and its implications for the development of rural economies', in de Haas and Tol 2017, op. cit. (n. 28), 51-82. See Anne Kolb's contribution in this volume with further literature.

48 M. Matteazzi, Il paesaggio trasformato. La pianura a sud di Padova tra Romanizzazione e Tarda Antichità (Oxford 2019), 85-101 and with a broader perspective R. Laurence, The Roads of Roman Italy: Mobility and Cultural Change (London and New York 1999).

49 C. Julien, 'The Chinchaysuyu road and the definition of an Inca imperial landscape', in Alcock, Bodel and Talbert 2012, op. cit. (n. 46), 147-167. Similar observations of powermessages by roads and milestones in Roman Spain are presented by Camilla Campedelli in this volume.

50 For aqueducts as an important part of this interconnected world of the Roman empire, see Saskia Kerschbaum's contribution in this volume with further literature for Asia minor. E.g. for some regions in Achaia, Alcock 1993, op. cit. (n. 4), 87-88; 12 o. 
Social engineering by a central government could also be the objective of forced migration as well as of supporting measures like tax releases for those willing to invest, rebuild or reshape a country shaken by the damages of war or natural disasters. Roman imperial "benefactions", like tax releases or building activities in Italy and the provinces and rebuilding after damages, was inherent to the paternalistic system of aristocratic and monarchic governments; however, the extent and frequency of investments were not.

Neither the large road network in many provinces and regions of the Roman empire, nor the granting of Roman and Latin city statuses' or the spreading of Roman citizenship - all with a major impact on the Romanness of the landscape, and the firmness and implicitness of the Roman grip on a region seem to have been part of a standardised feature or developing trait of Roman imperialism over a longer period of time..$^{52}$ No doubt, the Roman road system extending to circa $100,000 \mathrm{~km}$ had a strong impact and was part of the main active forces for the integration and development of the parts of the Roman territory. ${ }^{53}$ With each volume, the Impact of Empire-series as such emphasises that bridges and roads linking all parts of the empire influenced peoples, cultures and politics all along the way and at its ends. ${ }^{54}$ It may go too far to speak of an "orthogonal Roman landscape", but R. Talbert's assertion that the Roman emperors and elite were not interested in a systematic or strategic development of the Roman road network on which so much depended in their empire, not only on an administrative and military level, can be doubted as well. ${ }^{55}$ However, Greek-speaking contemporaries from the first century BCE to the late second CE praised the greatness of the empire visible in these infrastructure development and maintenance (e.g. D. H. 3, 67, 5). Less spectacular was the development of rural landscapes, not just because of the establishment

52 Ph. Leveau, 'Temps, espace et structuration des paysage', in G. Chouquer (ed.), Les formes des paysages, Vol. 3 L'analyse des systèmes spatiaux (Paris 1997), 14-24 draws particular attention to the linear axis of Rome's structuring of southern Gaul by land lots and roadnetwork creating an orthogonal Roman landscape, whereas areas that were not on the main roads and far from the colonies remained non-orthogonal. By contrast, R. Talbert, 'Roads not featured: A Roman failure to communicate?', in Alcock, Bodel and Talbert 2012 op. cit. (n. 46), 235-254 argues that in the republican and imperial period, there existed no data collection, no standard management, no envision of the roads as a comprehensive entity.

$53100,000 \mathrm{~km}$, see Kissel 2002, op. cit. (n. 46), 127. In this context the term „active force" is used by Alcock, Bodel, Talbert 2012, op. cit. (n. 52), 5 .

54 For the IMEM-series and the foci of the volumes, see the list at the end of the contribution of Marietta Horster and Nikolas Hächler in this volume.

55 Talbert 2012, op. cit. (n. 52). Contra, e.g. A. Kolb, 'Herrschaft durch Raumerschließung Rom und sein Imperium', in O. Dally et al. (ed.), Politische Räume in vormodernen Gesellschaften. Gestaltung - Wahrnehmung - Funktion, (Rahden, Westf. 2012), 71-85. 
of better connections of countryside and cities and a facilitated transfer of agricultural goods. The regions, integrated into the empire with its network of roads, lost their local orientation and small scale economic function. ${ }^{56}$ This changed any landscape in its ideological framing as well as its physical ends.

From the first to the fourth centuries, the awareness of the importance of the road network as well as the responsibility of supervision and maintenance by the provincial governor is attested by thousands of milestones all over the empire. Crossing landscapes by using roads with rather strong optical, manmade signals, might qualify the perceived environment as Roman. Roman interregional roads were characterised by milestones of more or less similar shape and size, but with slight variants in wording and therewith referred authority. At least in parts of Italy and some provinces, small sanctuaries at crossroads honoured the Roman Lares compitales or Quadruviae deities. ${ }^{57}$ These deities seem to have a strong integrating effect.

Other inscribed objects turned an impressive "natural" feature into a Roman feature. At the alpine pass Grand St. Bernard, the Celtic god Poeninus merged with the supreme Roman god Jupiter and probably soon lost its Celtic character, but not its name (Iupiter Optimus Maximus Poeninus and similar). Next to the road of this important pass, he was venerated in a Roman temple as a Roman god with Celtic roots into the fourth century CE by Latin inscribed votive tablets. ${ }^{58}$ At least at some of the stationes at the limes and near the border along the large roads in the provinces, soldiers were stationed for the control of goods and people, thus providing a massive, perhaps even positive Roman impact while travelling, offering greater safety for travellers. Next to these small garrisons, inscribed altars were offered to Jupiter Optimus Maximus

56 R.B. Hitchner, 'Roads, integration, connectivity, and economic performance in the Roman empire', in Alcock, Bodel and Talbert 2012, op. cit. (n. 46), 222-234, esp. 23 o.

57 For the integrating aspect of the shrines at crossroads and the popular cult of the Lares in the city of Rome, see H. Flower, The Dancing Lares and the Serpent in the Garden: Religion at the Roman Street Corner, Princeton 2017, 253-254; for the Italian inscribed evidence of a cult of Lares at compita, ibid., 226-233. For altars (not sanctuaries, as it seems) at crossroads and non-identifiable other places offered to the tutelary gods of travel, boundaries and roads in the two Germaniae provinces, see D. Schmitz, 'Weihbezirke an Wegekreuzungen? Inschriften zu den Wegegöttinnen und archäologischer Befund: das Fallbeispiel Nieder- und Obergermanien', in A. Busch and A. Schäfer (eds.), Römische Weihealtäre im Kontext: Internationale Tagung in Köln vom 3.-5. Dezember 2009 (Friedberg 2014), 281-299.

58 Votive tablets name Poeninus: e.g. CIL V 6866; InscrIt 11/1, 87.90. Iupiter Poeninus: e.g. CIL V 6867; Iupiter Optimus Maximus Poeninus: e.g. CIL V 6865. 6868-9; InscrIt 11/1, 93. 
by the beneficiarii, the respective head of such a small group of soldiers, thus Romanising such a landscape in a religious way. 59

Roads marked a landscape as Roman not because they were built by Romans and laid throughout the Roman empire. Roads were Roman because of their density in comparison to previous road systems, because of their solid paving, their having such marked signs as milestones with or without Latin inscriptions, because they allowed commodities such as garum, wine and olive oil to be transported from one Roman province to another. Perhaps more important was the role of communication and social connectivity as Roman roads linked Roman cities, villae rusticae and military camps, Roman business partners, religious groups, families and friends. ${ }^{60}$ The tabernae, lodgings, and changing stations (mutationes) along the long roads were used by Romans and nonRomans, by rich and poor, by private and official travellers.

Around $300 \mathrm{CE}$, the Antonine Itinerary counted over 700 roads. Its long lists with precise distance indications in Roman miles "visualised" the connectivity of the empire not through a map, but a register, integrating some 2000 smaller settlements and larger cities in this Roman road network. ${ }^{61}$ The registers list road sections from one city to another; provincial boundaries have no consequences for the road registers. The roads depicted by words as well as in the roads outside in the landscape connected people within the empire as a whole, ${ }^{62}$ whereas many of the stations mentioned above with their Roman

59 E. Schallmayer, Der römische Weihebezirk von Osterburken I. Corpus der griechischen und lateinischen Beneficiarier-Inschriften des Römischen Reiches (Stuttgart 199o): e.g. from Osterburken CвI 148 Iupiter Optimus Maximus, Iuno Regina, the Genius loci, and all other gods; $C B I 149$ the same selection excluding the other gods; $C B I 500$ the same choice of gods as in 149, including Mars Exalbiovicus. For the stations, their functions and the garrisoned soldiers see, J. Nelis-Clément, Les beneficiarii: militaires et administrateurs au ser-

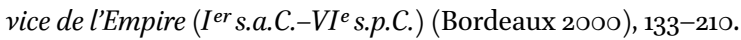

6o Connectivity is discussed by Hitchner 2012, op. cit. (n. $5^{6}$ ), who underlines the (methodological) difficulties to link Roman infrastructure and flow of goods. See as well the papers of Filippo Carlà-Uhink and Anne Kolb in this volume pointing to different concepts of connectivity during republic and empire and empire-related visions of roads in Italy (Carlà-Uhink) and the provinces (Kolb).

61 For a discussion of the function of the Intinerarium Antonini, see B. Löhberg, Das "Itinerarium provinciarum Antonini Augusti": Ein kaiserzeitliches Straßenverzeichnis des Römischen Reiches, Berlin 2006, 1-3; M. Maas and R. Derek, 'Road connectivity and the structure of ancient empires: A Case Study from Late Antiquity', in Alcock, Bodel and Talbert 2012, op. cit. (n. 46), 255-264.

62 Löhberg 2006, op. cit. (n. 61), 49 the longest terrestrial connection starts in Rome and ends in Upper Egypt after 6,o98 km, another such long "road" is the route from Carthage to Alexandria with $2,739 \mathrm{~km}$. 
military and religious context were social and visual markers next to the near border outside of the empire.

Borders of territories (cities, provinces or the Roman empire) and (Roman or local) institutions have an important impact on creating a regional identity. ${ }^{63}$ Cult and sanctuaries are one of the institutions which greatly identify a community or group. Within a few generations, the locally dominated Italian sacred landscape was changed with and by Rome's expansion in the republican period; ${ }^{64}$ the impact on the provinces started later, took a longer time and had different results in the West, East, North and South of the empire. On the surface and compared to other regions of the empire, there were no major changes for the structure based on the Nile-economy of Roman Egypt compared to the Ptolemaic period. ${ }^{65}$ However, even in a province such as Egypt, shifts of size and composition of administrative units or frequentation of the long distance roads were connected to changes of religious preferences and therewith the sacred landscape. The Roman emperor had to be worshipped instead of the Hellenistic king and the relationship between the Egyptian-Hellenistic religious traditions and the interpretatio Romana of some cults was renegotiated. There have also been demographic changes in Alexandria and some other regions of Egypt and with it ritual traditions not only in the religious sector.

\section{$4 \quad$ Ritual Performance and Religious Facets}

Rituals, ritual performances and practices are not reduced to cult-related activities, but to religious, judicial and political public and many private activities determined by a sequence of gestures, words and actions. ${ }^{66}$ In this broad

63 Boundaries, but e.g. also institutions and symbols as important agents in creating a regional identity are presented by A. Paasi, "The resurgence of "region" and "regional identity". Theoretical reflections with empirical illustrations', in R. Barndon, A. Engevik jr. and I. Øye (eds.), The Archaeology of Regional Technologies. Case Studies from the Palaeolithic to the Age of the Vikings (Lewiston et al. 2009), 15-33.

64 For cult and sacred places as internal identity-support, see T. Stek, 'Cult, conquest, and "religious Romanization". The Impact of Rome on Places and Religious Practices in Italy', in T. Stek and G.J. Burgers (eds.), The Impact of Rome on Cult Places and Religious Practices in Ancient Italy (London 2015), 1-28. For detailed studies on these changes, see T. Stek, Cult places and Cultural Change in Republican Italy: A contextual Approach to Religious Aspects of Rural Society after the Roman Conquest (Amsterdam 2009).

65 However, even in Roman Egypt, there were considerable changes of land tenure regulations, administrative geography, and social ramifications inter alia as responses to environmental behaviour and fiscal challenges, Blouin 2014, op. cit. (n. 36).

66 V.P.J. Arponen and A. Ribeiro, 'Ritual and landscape. Theoretical considerations', in Haug et al. 2018, op. cit. (n. 5), 73-84 give a short insight into the potential of post-processual archaeological approaches for the interdisciplinary analysis of ritual landscapes. 
context, the fixed founding rituals, those for land division, the innumerable rites in the context of sowing and harvesting, thanksgiving rituals offered to the gods after a journey or because of childbirth, ritual processions outside of the city to a rural sanctuary - all of these mark the territories outside the city walls. Focussing on the religious aspect, performances and ritual are but one aspect of forming a "sacred landscape", but the most difficult to grasp by archaeological, historical and philological methods of research. ${ }^{67}$

Related to the broad areas of ritual and religious studies, sacred landscapestudies have become a research area of their own. ${ }^{68}$ They incorporate two main vantage points. The first concerns the location, the presentation and architectural features, the meaning and offers of interpretation and the relevance of sanctuaries and cult places for a given group or society and their relationship with others. An exemplary field of research is Cyprus questioning the relatedness of local insular tradition and the global imperial impact during the Roman period:69 "The number of sanctuaries surviving into or built during the Roman period suggest that extra-urban sanctuaries within the new unified political organisation eventually lost one of their most important connotations: their 'territorial' implication." Papantoniou claims that these sanctuaries were marginalised losing their rural visitors due to changes in settlement patterns in the first century CE. Moreover, Cyprus was 'provincialised' with shifts of reference points to a Rome-related history and Rome-focused local elite policy, creating new memories and traditions. Most often, this kind of landscape-approach concerns material and art historians studies, yet with wide ranging consequences for the interpretation of religious notions, beliefs

67 C. Moser, "The architecture of changing sacrificial practices in Pre-Roman and Roman Gaul', in S.E. Alcock, M. Egri and J.F.D. Frakes (eds.), Beyond Boundaries. Connecting Visual Cultures in the Provinces of Ancient Rome (Los Angeles 2016), 174-189 discusses if changes in offering practices and sacrifices had consequences for the organisation of the sacred space in which the rituals take place.

68 For the Greek context, see M. Horster, 'Religious landscape and sacred ground: Relationships between space and cult in the Greek world', in Revue de l'histoire des religions, 227 (2010), 435-458; for the Greek imperial period, Alcock 1993, op. cit. (n. 4), 172-214. Since 2011, A.K. Vionis, G. Papantoniou and others are researching on developments of the sacred landscape of Cyprus from iron age to the Christian era, e.g. G. Papantoniou, 'Cyprus from basileis to strategos: A sacred-landscape approach', AJA 117 (2013), 33-57, here 33 he "explores how spatial order (i.e., the hierarchical arrangement of sites), as observed in sacred landscapes, is expected to articulate social order and to be linked with shifting relations of power and cultural influence in an ancient Cypriot context." An excellent introduction into the subject is provided in chapter 2 of C. Williams, Urban Rituals in Sacred Landscapes in Hellenistic Asia Minor, Leiden and Boston 2021, investigating into the country sanctuaries and ritual connectedness of the territories and cities of Mylasa, Labraunda, Sinuri, Stratonikeia and Lagina.

69 Papantoniou 2013, op. cit. (n. 68), $5^{2}$. 
and norms. Since the 199os, the study of sacred landscapes in the Roman context takes into account settlement patterns, imaginary worlds and conceptions of the ancients. ${ }^{70}$ This broader religious and cult-related perspective of landscapes is implemented for the study of all types of texts, from documents to poetry (e.g. inscribed votive, 'sacred laws', literature from Hesiod to late antique church history). Pausanias' second-century CE Periegesis is a special case as his text centres around informing about sacred places and cult rituals of the Pre-Roman period, at the same time transporting religious notions of his contemporary Roman Greece. ${ }^{71}$ In Pausanias' vision of ancient Greece, strength and greatness of a now (nearly) lost world is still audible in stories (which he therefore tells), and visible for his imperial period contemporaries in briefly mentioned or sometimes extensively described sanctuaries and places of worship. Pausanias' text constantly refers to the extra-textual reality and reminds his readers of cult-related role models, of heroes worshipping the gods and of famous creators of rituals. ${ }^{72} \mathrm{He}$ underlines the local and emblematic specialties and curiosities as the (inter)national traditions and relatedness of the Greeks within religion and cult practice. The latter is one of the essential foundations for an alternative perspective on sacred landscapes. This field of research attempts to grasp the performative aspect of cult and religious expression, not only through texts and images, but also by examining the finds from a sanctuary. Archaeozoology, for example, has made an important contribution here. However, the analysis of animal bones in sanctuaries has given rise to further investigations of sacrificial practices (e.g. absence of specific bones, size and number of altars), communal feasting (places, hierarchies of participants, arrangements), gender-based preferences (gender, age and size of sacrificed animals) and concepts of the divine and individual gods (kind and frequency of offers). Sacred landscapes created by material objects and (alleged) ritual activities are based on religion and geography at a particular point in time. They reflect the socio-political mediation of the participants involved and of those absent and refer to the institutional organisation of a group or society.

$70 \quad$ E.g. by Alcock 1993, op. cit. (n. 4), 175-181 on Roman Greece, by Papantoniou 2013 op. cit. (n. 68) on Roman Cyprus. T. Derks, 'The transformation of landscape and religious representation in Roman Gaul', Archaeological Dialogues 4 (1997), 126-147, esp. 145, with a discussion of his arguments, ibid., 148-163; Stek 2009 op. cit. (n. 64) for Italy.

71 V. Pirenne-Delforge, 'Ritual dynamics in Pausanias: The Laphria', in E. Stavrianopoulou (ed.), Ritual and Communication in the Graeco-Roman World (Liège 2006), 111-129 with an exemplary study on the relatedness of space and ritual in Pausanias.

72 For Pausanias' religious sights as a literary space of stories, see J. Akujärvi, 'Pausanias', in I. de Jong (ed.), Space in Ancient Greek Literature, Studies in Ancient Greek Narrative 3 (Leiden/Boston 2012), 235-255, here 238-240. 
Connected by architecture, ritual, landscape, human behaviour etc., this kind of network is dynamic and open for development. Some objects, architectures or texts might have triggered specific mind-sets or memories, integrating them into the mental map of religion, cult or ritual of the respective visitors of the sanctuary, user of the object, participant in the ritual or reader of the text. In the case of textual evidence rather than material findings, the ritual and sacred landscapes, as e.g. created by Strabo's, Pausanias', Vergil's or Tacitus' works, follow other compositional features and reflect the (social) world of objects and literature. The dynamic lies in the revisited landscape of the reader and interactive reading process. Although the ancient educated readers had a common library with the most important texts and authors as a basis, further readings differed greatly, probably according to personal preferences, experiences and individual social and professional life and life time. Our reduced knowledge of the world of texts read e.g. by the elite members living in Southern Gaul in the mid-second century CE, reduces the potential and openness of the texts that have survived the medieval and byzantine selection processes.

Literature creates landscapes in more than one sense. Narrated space-forming landscapes are an important medium to "devise (spatially) coherent worlds".73 Country settings may as well be combined with stylistic features like purity (mountain springs), roughness (mountains) or decoration (flowers andidylls). ${ }^{74}$ There are geographically defined genres, such as the classical Attidography or late republican Strabo's geography. ${ }^{75}$ Some motives like travelling and wandering require landscape-settings as a combination of spatial, ethnographical, adventurous and/or civilising storytelling. ${ }^{76}$ According to de Jong, there are several literary strategies of why and how to introduce space, similar to the mirror function of synoptic descriptions or of a person's character, and the symbolic function charging a scene with an additional meaning, transporting

73 M. Skempis and I. Ziogas, 'Introduction. Putting epic space in context', in M. Skempis and I. Ziogas (eds.), Geography, Topography, Landscape. Configurations of Space in Greek and Roman Epic (Berlin et al. 2013), 1-18.

74 N. Worman, Landscape and the Spaces of Metaphor in Ancient Literary Theory and Criticism (Cambridge 2015), 2-6.

75 K. Clarke, Between Geography and History: Hellenistic Constructions of the Roman World (Oxford 1999), 193-244 for Strabo.

76 Skempis and Ziogas 2013, op. cit. (n. 73), 5 with further literature for Greek and Roman traditions including narratives of colonization grounded in mythical structures. 
values and emotions. ${ }^{77}$ Literary landscapes are rooted in narratology traditions of a detailed ekphrasis sometimes having an ornamental function, sometimes, as is the case in Latin epic, leading to action or preparing a change in the storyline. ${ }^{78}$ Setting a story in a real place, the author offers familiarity to his readers, whatever fantastic and novelistic turns the narrative will take. ${ }^{79}$ Place names and etiological explanations transform a space into a landscape. Such narratives join heroes or people and stories with a spatial configuration, transforming and appropriating the landscape ${ }^{80}$ Quite explicit in the Aeneid, Virgil connects Roman political power of his days with a teleologically narrated certainty that all of Italy (even before it existed as a unit) was destined to come under Roman rule (Aen. 1.279).

The following passages reduce the multifaceted aspects of literary creativity to but few aspects of the representation of (civilised) nature and landscapes in which social interaction takes place. Italian Campania is a good example to start, as it is the historical setting as well as the narrated space of the second Punic war with humiliation and losses for the Romans, and it continues to be a battlefield during the Civic wars of the first century BCE. ${ }^{81}$ It becomes a leisure landscape, a place of retreat and a locus amoenus for the rich and educated Romans during the late republic and the early empire - in a "real" world as villa architecture attests, as well as in epistles and poetry. ${ }^{82}$ In such a landscape, educated men and literary circles meet, literary competition and criticism takes

77 I.J.F. de Jong, 'Introduction: narratological theory on space', in I.J.F. de Jong (ed.), Space in Ancient Greek Literature (Leiden 2012), 1-18, here 13-17. Most of the general functions work for Latin literature as well, W. Fitzgerald, E. Spentzou, 'Introduction', in W. Fitzgerald, E. Spentzou (eds.), The Production of Space in Latin Literature, Oxford 2018, 2-21.

78 T. Behm, 'Landscapes in Latin epic', in C. Reitz and S. Finkmann (eds.), Structures of Epic Poetry. Vol. 1: Foundations (Berlin 2019), 325-359 with further references. Longer landscape descriptions or a short spatial setting may foreshadow the action; the character of a landscape gets more prominence when heroes are in search of the "right" place like Vergil for Aeneas or Ovid and Claudian for Ceres.

79 I. de Jong, Narratology and Classics: A Practical Guide (Oxford 2014), 108.

80 M. Skempis, 'Phenomenology of space, place names and colonization in the "CaietaCirce” sequence of Aeneid 7', in Skempis and Ziogas 2013, op. cit. (n. 73), 291-324 argues with Virgil's semanticisation of spaces and aims to demonstrate "how literary relations merge into spatial configurations" (p. 292). For the rather slow development of the idea (and for the language used for it) of Italy as a geographical unit see Carlà-Uhink 2017, op. cit. (n. 14).

81 E.g. for the Punic War landscape setting in poetry: Silius Italicus, Punica, 7 and historiography: Livy 23.45. For Campania in different literary genres, see E. Stärk, Kampanien als geistige Landschaft: Interpretationen zum antiken Bild des Golfs von Neapel, München 1995.

82 E.g. Domitian's villas in Mart. 5.1.1-6. See, C. Connors, 'Imperial space and time: the literature of leisure', in O. Taplin (ed.), Literature in the Greek \& Roman Worlds. A New Perspective (Oxford 2000), 492-518; D. Spencer, Roman Landscapes: Culture and Identity (Cambridge 2010), 62-134 for the manifold meanings given to villa landscapes in Italy by 
place, and it provides the perfect setting for literary production. ${ }^{83}$ Pliny's Tu felix ille Campania (Plin. Nat. 3.6o) refers to this and much more: Campania is also the agriculturally rich, green and lovely countryside of the Flavian period as described by Plinius the Elder, Statius and Martial. From time to time, it shows its dangerous side with the outbreak of the Vesuvius, most destructive in 79 CE. However, besides the volcano, Campania has a dark side with the Italian entry to the Underworld in the Phlegraean fields and the bay of Naples with its fabulous grottos seduce men of power and wealth to extravagances of all kinds, sometimes damaging the reputation of other wealthy men or even emperors. ${ }^{84}$ The poet Statius presents his native region Campania for its beauty, history and cultural values and praises the emperor Domitian for his investment into infrastructure, building the road Via Domitiana that connected Rome with Puteoli. ${ }^{85}$

Sometimes, it is not a specific landscape like Campania, but an all embracing category or keyword that is sufficient to create a literary spatial setting. Defeated Greek general Polybius' motivation to write his 'History' is grounded in Rome's subjection of almost the entire inhabited world within a short time of less than 53 years (Pol. 1.1.5). ${ }^{86}$ The keyword oikumene is enough to reduce and appropriate an enormous space to a Roman landscape. ${ }^{87}$ This is Polybius' narrated space - the inhabited, Roman dominated world. In this spatial context, he is programmatically interested in measuring this world. Therefore, he presents distances and landscapes for battle narratives as a kind of technically appropriate geographical information. ${ }^{88}$ Some 200 years later, another representative of a conquered people, Flavius Josephus, takes a decidedly different perspective. He does not tell a Roman story to the Greeks (or in his case the Jews), but a Jew's story to the Romans (and Greeks). In a context of historiography and war narratives similar to those of Polybius, Flavius Josephus rather

Cicero, Varro, Columella, Statius and Pliny the Younger. See as well Anne Gangloff's paper in this volume.

83 A. Augoustakis, 'Campania in the Flavian poets' Imagination', in A. Augoustiakis and R.J. Littlewood (eds.), Campania in the Flavian Poetic Imagination (Oxford 2019), 3-12.

84 É. Wolff, 'Martial and Campania', in Augoustakis 2019, op. cit. (n. 83), 75-82.

85 Smolenaars 2006, op. cit. (n. 13); Augoustakis 2019, op. cit. (n. 13), 8.

86 Clarke 1999, op. cit. (n. 75), 98-101 Polybius, a self-confident author and historiographer, admires the Roman conquerors but does not adopt the Roman standpoint keeping the Greek (conquered) one. For poetic perspectives on centre (Rome, Italy) and periphery (Egypt and other provinces), see W. Fitzgerald, 'The space of the poem', in W. Fitzgerald, E. Spentzou (eds.) op. cit. (n. 77), 147-166.

87 Clarke 1999, op. cit. (n. 75), 77-128: Polybius "subordinates space to time" (p. 119), to narrate a continuous story of the unification of the world by the Romans. With oikumene Polybius defines an enclosed, defined space: the inhabited world, whereas Virgil's imperium sine fine (Verg. Aen. 1.279) attributes Rome an open, unlimited space. Cf. V. Rimell, The Closure of Space in Roman Poetics. Empire's Inward Turn (Cambridge 2015), 28-31.

T. Rood, 'Polybius', in de Jong 2012, op. cit. (n. 72), 179-197. 
speaks of the beauty of his home country and the stories connected to Judaea and Israel. He entangles these narrated landscapes with Jewish perspectives and history, as if to prevent these landscapes from becoming Roman within a Roman province as part of the Roman empire. ${ }^{89}$ In contrast to the provincial perspective of Josephus, in the world of poetry at least, some authors with a Roman perspective have built metaphorical bridges between the provincial, yet "uncivilised" world and Roman culture with landscape settings, like a frozen river allowing the crossing between cultural and mental borders. ${ }^{90}$ One should keep in mind that not only rivers and other 'natural' features or heroes and literary (historical or imagined) personae leave their traces in the narrated landscapes, but the authors as well. In this perspective, narrated Latium has become Virgil's landscape, Aeneas' mythological-poetic property as well as Rome's spatial future.

In many ways, art has an analogous framework for literary production and reception and similar modes for the process to create a landscape. In contrast to verbal art, the aspect of intercultural interaction was a strong stimulus for creativity in the visual arts. Spatiality is another big difference influencing the creation and perception of an artefact. Art is linked to the space in which it is presented, to the function of the wall in a room adorned by a painting and to the social and geographical framework in which the room itself is located. An assemblage of several art works creates new effects for all and for each of them, and this interaction changes the perception of the viewer. Therefore, when examining the iconographic elements of a landscape, its integration into the social and spatial context is important. Unfortunately, this is often not possible because the necessary information is unknown. ${ }^{91}$

Metalanguage is strong enough to describe varieties, effects, modalities and functions of literary landscapes; however, it seems more appropriate to transport a more 'visualising' effect by using a different language to get an exemplary impression of such aspects connected to landscapes of artworks: ${ }^{22}$ "In the late $70 \mathrm{CE}$, dinner guests arriving at the large Pompeian house known today as the

89 Von der Bruegge 2016, op. cit. (n. 5), 36-38; 45-50 with further references to Josephus' creation of a "land of the Jews" as a "Josephan national geography".

90 C. Pieper, 'Polyvalent Tomi: Ovid's landscape of relegation and the Romanization of the Black Sea region', in McInerney and Sluiter 2016, op. cit. (n. 17), 408-430.

91 A short overview of developments in studies of paintings in antiquity within the last decades is provided by M.E. Fuchs, 'Regards sur la peinture antique', Perspective. Actualité en histoire de l'art 2010, 249-256, but see as well further literature in Abigail Walker's paper in this volume.

92 Barrett op. cit. (n. 2), 1 in his prologue before he starts his analysis of the Aegyptica-fashion in Pompeii. For Pompeian painted landscapes, see Walker op. cit. (n. 91). 
'Casa dell' Efebo' would have found themselves navigating a landscape at once both foreign and familiar. Within the garden stood a pleasant outdoor dining area: a masonry triclinium shaded from the afternoon heat by a vine-covered canopy. Splashing water from a nearby fountain filled a small channel to the triclinium benches, creating the impression that the diners were reclining on a riverbank. Outdoor dining areas of this type were a familiar sight in Roman Italy, but certain aspects of this particular installation simultaneously suggest more distant landscapes. As visitors came closer to the triclinium, they would have noticed a painted frieze on its benches depicting scenes of festival, cult, and banqueting along the banks of the Nile. The characters populating this painted landscape would have struck Pompeian viewers as unusual in a number of ways. Depicted as dwarfs or pygmies, their very bodies mark them as fundamentally different from their presumed viewers. Their behaviours, too, seem intended to be read as 'exotic,' 'foreign' customs: they perform worship before Egyptian animal gods, do battle with crocodiles and even engage in public sexual acts on the riverbank." Vivid and exotic banqueting in the painting and noisy, smelling, tasting "real" banqueting in front of the frieze merged and probably created something completely different than what was so nicely described by Barrett: perhaps crocodile-look-alike pastry was served during dinner by Egyptian-clothed servants creating an evening in an Italo-Egyptian setting ... However, often enough, literature was also taken out of the individual reading room and was read aloud or performed for a group. Whereas modern investigations of literary antique landscapes take into account the individual recreating process while reading, the performative and contextualised event (in a banquet context, in the otium-villa or in busy Rome) for an individual or a group is often forgotten. It seems, as if space and performative, cultural and social context also had an impact on the potential (emotional or intellectual or both) interpretation of a literary landscape, as it did on that of an artwork. And, finally, commissioned work plays an important role in artcreated landscapes, ${ }^{93}$ whereas this is also known for poetry, it is less manifest in literature, as copies could transcend time and space and access to originals, visual or textual was but rare. ${ }^{94}$

93 However, N.B. Jones, Paintings, Ethics, and Aesthetics in Rome (Cambridge 2019), 137-178 argues that artists had the freedom for innovation of genres and themes in mythological and landscape painting, and an engagement with the subject of representation in panel painting.

94 On the rare access to originals and the role of copies see, J.P. Small, 'Visual copies and memory', in A. Mackay (ed.), Orality, Literacy, Memory in the Ancient Greek and Roman World (Leiden 2007), 227-251. 
Similar to wall paintings, mosaics are the result of artwork and technical craft. Nile motifs as those mentioned in wall paintings as part of the Aegyptiaca-fashion are known from mosaics as well. Both, paintings and mosaics respond to the taste and wishes of the client, probably offering and creating what is modern or fashionable. In a Roman styled villa, mosaics offered a flat and waterproof surface with decoration. Such decorated, often artful floors were to become an important means to display the wealth, status and taste of the owner of the house, ${ }^{95}$ even more so in provinces of the Roman empire, where there had existed no pre-Roman experience and production tradition, like in Roman Germany or Britain in contrast to Greece and Italy. The very few late antique 'maps' that have survived as mosaics are often interpreted in a cartographic and political context, but they are also decorative and artful representations of landscapes comparable to a Nile or maritime or garden motif representation. The sixth-century Madaba map is such a floor mosaic of a church..$^{96}$ Because of its ecclesiastical context, it was interpreted as an idiosyncratic Christian world view with a selection of geographical conditions (rivers, deserts, mountains) and social forms of organisation (cities, villages) often represented by city walls and churches. ${ }^{97}$ Many of the maps that existed on papyrus and parchment (Suet Dom.10.3) were not preserved. ${ }^{98}$ Other Roman census or city-related maps, such as the Forma Urbis Romae of the Severan period, were carved in marble or engraved in bronze. ${ }^{99}$ Such maps seem to have had an

95 An overview of mosaics as part of Rome-related intercultural negotiation is given by W. Wooton, 'A portrait of the artist as a mosaicist under the Roman empire' in Alcock, Egri and Frakes 2016, op. cit. (n. 67), 62-83. For the mosaicists workshops and individual craftsmen in a Roman provincial Eastern setting with previous longstanding non-Roman mosaic-traditions, see R.J. Sweetman, The Mosaics of Roman Crete (Cambridge 2013), 116 136. Sweetman does not use the term 'landscape' when describing motives and genres but speaks e.g. of a "marine scenes" with fishermen at a shore (ibid., 189).

96 The 'Madaba map' is a floor mosaic in the Saint Georg Church of Madaba in Jordan. Originally, it measured $21 \times 7 \mathrm{~m}$ of which $16 \times 5 \mathrm{~m}$ are still existent. H. Donner and H. Cüppers Die Mosaikkarte von Madeba (Wiesbaden 1977). It covers the modern states of Jordan, Israel, Lebanon, Egypt and the Palestinian territories.

97 B. Leal, 'A reconsideration of the Madaba map', Gesta 57 (2018), 123-143 argues that it was originally designed for a secular building.

98 One of the first c. BCE: C. Gallazzi, B. Kramer and S. Settis, Il papiro di Artemidoro (Milan 2008). For a short overview of illustrated texts of antiquity, see J.P. Small, The Parallel Worlds of Classical Art and Text (Cambridge 2003), 118-154.

99 Census and centuriation related maps are mentioned in many of the Gromatici Latini authors. Such maps were supposed to guarantee legal security of the properties involved, see above n. 22. See Campbell 200o, op. cit. (n. 19), LVII with reference to the fragmentary map of a land surveyor from Augusta Emerita in Spain; S. Keay and G. Earl, 'Towns and territories in Roman Baetica', in A. Bowman and A. Wilson (eds.), Settlement, Urbanization, and Population (Oxford 2011), 277-316, esp. 285 on the cadastral map at Arausio (Orange) 
administrative and fiscal function and the explanatory legends were of highest importance. ${ }^{100}$ The inscriptions of the Madaba map mosaic, and the legends of the Peutinger Table seem to have had a different purpose, but were both part of the overall composition of a specific landscape. ${ }^{101}$ Similar to the thirdcentury CE map on a parchment from Dura Europos, ${ }^{102}$ both artworks create a political (and theological?) interpretation of the landscape of the late Roman and early Byzantine empire through their subject matter, but even more so through the choice of objects and their arrangement and layout. In the late antique Roman empire emblematic visualisation of the Tabula Peutingeriana as in the literary design of Pausanias' imperial Greece, the 'narrative' moves from landmark to landmark connected by routes. These landscape portrayals of the Roman world, which lie several centuries apart and work with different media, unlock the civilised world by the ordering principle of itineraries. ${ }^{103}$

Political Landscapes

It goes without saying that Rome set many visual markers in the landscapes of the empire, not just paved roads and milestones, aqueducts and military camps. These and other infrastructure measures changed the way and intensity of communication, transport, supply, travelling, and migration. All the above discussed landscapes were Roman in a substantial political way - they were

in Gallia Narbonensis and the fragmentary map of Lacimurga in Spain; for Lacimurga and similar maps with further literature, Hettinger 2017, op. cit. (n. 21).

100 For an overview see O.A.W. Dilke, 'Maps in the service of the state: Roman cartography to the end of the Augustan era', in J.B. Harley and D. Woodward (eds.), The History of Cartography. Vol. I: Cartography in Prehistoric, Ancient and Medieval Europe and the Mediterranean (Chicago and London 1987), 201-211; for military maps, see R.K. Sherk, 'Roman geographical exploration and military maps', in ANRW 1 (Berlin 1974), 534-562.

101 For the Tabula Peutingeriana see Silke Diederich's contribution in this volume with references to further literature.

102 P. Arnaud, 'Une deuxième lecture du bouclier de Doura-Europos', CRAI 133 (1989), 373389 with good arguments that the Dura-Europos map did not cover a shield (as the context of its finding suggests and most publications report), but that it was a pinax probably originating from the Balkan region.

103 Talbert 2012, op. cit. (n. 52), 235-264 underlines that the Peutinger Table is a cartographic propaganda with street lines being the main characteristic of the empire. For an overview of the few surviving maps with pictograms and roads see the overview of O.A.W. Dilke, 'Itineraries and geographical maps in the early and late Roman empire', in Harley and Woodward 1987, op. cit. (n. 100), 234-257. For Pausanias, Akujärvi 2012, op. cit. (n. 72), 241-245; and compare Clark 1999, op. cit. (n. 75), 26 with reference to selection processes and choices by map-makers and literary geographers of what to present and how. 
created by Roman means (objects, monuments, inscriptions, Latin language etc.) and they oriented towards a centre, Rome, even if Rome was invisible or, if at all, formed the background like a faint noise. This centrality formed spatial structures throughout the empire through hierarchisation: physical nearness to the political and financial centre of the empire (e.g. Latium and Campania, Southern Gaul), economic potential (e.g. western Asia minor) and relevance for the supply of Rome (e.g. Egypt, North Africa, oil from Spain), cultural relevance for the political and educated elite (e.g. Athens), divine protection for Rome and the empire (e.g. early imperial Latium) or individual members of the elite (e.g. Eleusis) etc. However, this Rome-relatedness was dynamic. The importance of a region for Rome depended not only on fiscal needs and access to resources, but also on military necessities.

The landscapes of the Roman empire also had a life of their own, if one can put it that way. Landscape forms arose and were sustained by local resources and constraints of the natural environment, demography and way of life, customs and beliefs, rituals and religion, self-awareness and history, language and art traditions. This local or individual involvement (in the case of an artist or author) was incorporated into the Roman framework and made a social, religious, ritual, economic etc. landscape look different in the Transpadana region than in the provinces of Cappadocia or Lusitania. Real, constructed or imagined, with long-term or short-term effects, Roman landscapes are shaped by the lives of its inhabitants. ${ }^{104}$

Landscape studies are a dynamic field of study in modern archaeology, history and philology and related fields synthesising various types of data, testing theories, and using a broad range of methods. The heterogeneous landscapes thus created attest to the connectivity, complexity, multi-identity and flexibility of the Roman empire as a space of power.

104 Gruppuso and Whitehouse 2020, op. cit. (n. 7), 594. 